\title{
COVID-19 and Diabetic Ketoacidosis: Report of Eight Cases
}

\author{
Balraj Singh $^{1}$, Prem Patel ${ }^{2}$, Parminder Kaur ${ }^{2}$, Nicole Majachani ${ }^{3}$, Michael Maroules ${ }^{4}$ \\ 1. Hematology/Oncology, Saint Joseph's University Medical Center, Paterson, USA 2. Cardiology, Saint Joseph's \\ University Medical Center, Paterson, USA 3. Internal Medicine, Saint Joseph's University Medical Center, Paterson, \\ USA 4. Hematology and Oncology, Saint Joseph's University Medical Center, Paterson, USA
}

Corresponding author: Balraj Singh, bsriar9@gmail.com

\section{Abstract}

\section{Aim}

To describe the clinical characteristics and outcome of hospitalized COVID-19 patients with diabetic ketoacidosis (DKA).

\section{Methods}

We report eight cases of diabetic ketoacidosis in COVID-19 who presented to our institution in New Jersey, USA. COVID-19 was diagnosed by nasopharyngeal swab reverse transcription polymerase chain reaction (RTPCR). The patients' electronic medical records were reviewed. Data on patients' age, sex, ethnicity, laboratory values, glycosylated hemoglobin level, oral antihyperglycemic agents (OHAs), insulin, and clinical outcomes were collected.

\section{Results}

The median age of the patient was 42.5 years, and seven were males and one was female. Out of eight patients, five had type 2 diabetes mellitus (DM), two had undiagnosed DM, and one had type $1 \mathrm{DM}$. Median value of initial glucose on presentation was $454 \mathrm{mg} / \mathrm{dL}$. Median value of HbA1c on presentation was $11.4 \%$ and of anion gap was $26.5 \mathrm{mEq} / \mathrm{L}$. Four patients had large ketonemia, one patient had moderate ketonemia, and three patients had small ketonemia. All the patients were started on standard treatment protocol for DKA with intravenous fluids and IV insulin infusion. Acute kidney injury (AKI) was seen in four patients, and one patient required renal replacement therapy. Out of eight patients, three required mechanical ventilation, and the same three patients died.

\section{Conclusion}

Our case series shows that COVID-19 infection can precipitate DKA in patients with known diabetes mellitus patients or as a first manifestation in undiagnosed DM patients; COVID-19 with DKA is associated with substantial mortality. Further studies are needed to characterize poor risk factors associated with mortality in these patients.

Review began 03/16/2021 Review ended 03/28/2021 Published 03/31/2021

\section{(c) Copyright 2021}

Singh et al. This is an open access article

distributed under the terms of the Creative Commons Attribution License CC-BY 4.0., which permits unrestricted use, distribution, and reproduction in any medium, provided the original author and source are credited.
Categories: Endocrinology/Diabetes/Metabolism, Internal Medicine, Infectious Disease

Keywords: type i diabetes mellitus, covid 19, diabetic ketoacidosis (dka), ketotic hyperglycemia, types 2 diabetes, sarcov 2 infection, diabetic hyperglycemic hyperosmolar syndrome

\section{Introduction}

The severe acute respiratory syndrome coronavirus 2 (SARS-CoV-2) is an enveloped novel RNA betacoronavirus responsible for the current global pandemic. It has led to a health crisis with rapidly increasing number of cases and fatalities. Although respiratory symptoms predominate, widespread organ-specific manifestations (gastrointestinal, neurological, thromboembolic, immunological, and cardiovascular) of COVID-19 are increasingly being reported. In-depth understanding of various systemic manifestations and complications of SARS-CoV2 is of paramount importance for optimal management of these patients.

As research into COVID-19 expands, knowledge of the endocrine effects is becoming better understood. Diabetes and obesity are common comorbidities associated with COVID-19 [1]. Comorbidities like cardiovascular disease, diabetes mellitus (DM), hypertension, chronic lung disease, cancer, chronic kidney disease, obesity, and smoking have been associated with severe illness and mortality [2,3]. A retrospective study from China found that high fasting glucose levels $\geqslant 126 \mathrm{mg} / \mathrm{dl}$ at admission was an independent poor prognostic factor in patients with COVID-19 who did not have diabetes mellitus [4]. A wide range of manifestations and outcome can occur depending upon the comorbidities of the infected patient. COVID-19 can precipitate metabolic complications of diabetes such as diabetic ketoacidosis (DKA) and hyperosmolar hyperglycemic state (HHS) [5]. 


\section{Materials And Methods}

We report eight cases of diabetic ketoacidosis in COVID-19 who presented to our institution in New Jersey, USA. COVID-19 was confirmed by real-time reverse transcription polymerase chain reaction (RT-PCR) assay. Diabetes was defined as glycated hemoglobin $(\mathrm{HbA} 1 \mathrm{c}) \geqslant 6.5 \%$ or any established diagnosis prior admission. DKA is defined by the triad of hyperglycemia, anion gap metabolic acidosis, and ketonemia or ketonuria. The patients' electronic medical records were reviewed. Data on patients' age, sex, ethnicity, laboratory values, glycosylated hemoglobin (HbA1c) level, oral antihyperglycemic agents (OHAs), insulin, and clinical outcomes were collected.

\section{Results}

Pertinent clinical characteristics and laboratory values are summarized in Table 1 .

\begin{tabular}{|c|c|c|c|c|c|c|c|c|}
\hline Variable & Case 1 & Case 2 & Case 3 & Case 4 & Case 5 & Case 6 & Case 7 & Case 8 \\
\hline Age/Sex & $35 / \mathrm{M}$ & $50 / \mathrm{M}$ & 33/M & $52 / F$ & 32/M & 63/M & 30/M & 66/M \\
\hline Ethnicity & $\begin{array}{l}\text { African } \\
\text { American }\end{array}$ & Hispanic & Hispanic & Hispanic & Hispanic & Bengali & Hispanic & Hispanic \\
\hline $\begin{array}{l}\text { Medical } \\
\text { history }\end{array}$ & DM & $\begin{array}{l}\text { HTN, DM, } \\
\text { DLD }\end{array}$ & None & $\begin{array}{l}\text { HTN, DM, DLD, } \\
\text { asthma, anxiety }\end{array}$ & DM & $\begin{array}{l}\text { HTN, DM, } \\
\text { BPH }\end{array}$ & HTN & $\begin{array}{l}\text { HTN, DM, } \\
\text { DLD, } \\
\text { asthma }\end{array}$ \\
\hline $\begin{array}{l}\text { Type } 1 \text { DM or } \\
\text { type } 2 \text { DM or } \\
\text { undiagnosed }\end{array}$ & Type 1 DM & Type 2 DM & Undiagnosed & Type 2 DM & Type 2 DM & Type 2 DM & Undiagnosed & Type 2 DM \\
\hline $\begin{array}{l}\text { Presenting } \\
\text { signs and } \\
\text { symptoms }\end{array}$ & $\begin{array}{l}\text { Generalized } \\
\text { weakness, } \\
\text { fatigue }\end{array}$ & $\begin{array}{l}\text { SOB, cough, } \\
\text { and chills }\end{array}$ & SOB, fever & SOB, dizziness & SOB, fever & $\begin{array}{l}\text { SOB, } \\
\text { vomiting, } \\
\text { nausea, } \\
\text { abdominal } \\
\text { chest pain }\end{array}$ & $\begin{array}{l}\text { SOB, fever, } \\
\text { chills, } \\
\text { hematemesis, } \\
\text { hematochezia }\end{array}$ & $\begin{array}{l}\text { SOB, bloody } \\
\text { diarrhea, } \\
\text { nausea }\end{array}$ \\
\hline $\begin{array}{l}\text { Home DM } \\
\text { medications }\end{array}$ & Insulin & $\begin{array}{l}\text { Insulin and } \\
\text { metformin }\end{array}$ & NA & $\begin{array}{l}\text { Insulin, } \\
\text { metformin, DPP4 } \\
\text { inhibitor, and } \\
\text { SGLT2 inhibitor }\end{array}$ & $\begin{array}{l}\text { Metformin } \\
\text { and } \\
\text { sulfonylureas }\end{array}$ & NR & NA & Metformin \\
\hline BMI & 22 & 24.09 & 41.88 & 27.92 & 25.65 & 26.7 & 55.1 & 33.83 \\
\hline HbA1c (\%) & 17 & 15.2 & 11.2 & 11.6 & 12.1 & 11.2 & 10.5 & 10 \\
\hline $\mathrm{pH}$ & 7.1 & 7.0 & 7.1 & 7.1 & 7.2 & 7.3 & 7.3 & 7.3 \\
\hline $\begin{array}{l}\text { Bicarbonate } \\
\text { (mEq/L) }\end{array}$ & 6 & 7 & 14 & 16 & 13 & 10 & 12 & 16 \\
\hline $\begin{array}{l}\text { Glucose on } \\
\text { presentation } \\
\text { (mg/dL) }\end{array}$ & 553 & 350 & 698 & 396 & 368 & 404 & 516 & 504 \\
\hline $\begin{array}{l}\text { Serum } \\
\text { ketones }\end{array}$ & Large & Large & Small & Moderate & Large & Small & Large & Small \\
\hline $\begin{array}{l}\text { Anion Gap } \\
\text { (mEq/L) }\end{array}$ & 28 & 28 & 27 & 14 & 24 & 32 & 26 & 22 \\
\hline $\begin{array}{l}\text { Effective } \\
\text { osmolarity } \\
(\mathrm{mOsm} / \mathrm{Kg})\end{array}$ & 280.7 & 281 & 294.78 & 298.00 & 284.44 & 294.44 & 298.67 & 282.00 \\
\hline $\begin{array}{l}\text { White cell } \\
\text { count }\left(\mathrm{K} / \mathrm{mm}^{3}\right)\end{array}$ & 9.1 & 11.6 & 13.4 & 23 & 10.3 & 7.1 & 9.4 & 12.6 \\
\hline $\begin{array}{l}\text { Hemoglobin } \\
(\mathrm{g} / \mathrm{dL})\end{array}$ & 12.7 & 14.8 & 14.3 & 14.1 & 14.9 & 14.5 & 11.9 & 7.6 \\
\hline $\begin{array}{l}\text { Platelets } \\
\left(\mathrm{K} / \mathrm{mm}^{3}\right)\end{array}$ & 133 & 298 & 291 & 245 & 223 & 230 & 344 & 155 \\
\hline
\end{tabular}




\section{Cureus}

\begin{tabular}{|c|c|c|c|c|c|c|c|c|}
\hline $\begin{array}{l}\text { Troponin } \\
\text { (ng/mL) }\end{array}$ & $<0.010$ & 0.036 & 3.84 & 0.153 & 0.01 & 0.01 & 0.01 & 2.293 \\
\hline $\begin{array}{l}\text { Sodium } \\
\text { (mEq/L) }\end{array}$ & 125 & 131 & 128 & 138 & 132 & 136 & 135 & 127 \\
\hline $\begin{array}{l}\text { Potassium } \\
\text { (mEq/L) }\end{array}$ & 4.8 & 5.1 & 5.6 & 3.8 & 3.9 & 4.0 & 4.1 & 4.9 \\
\hline $\begin{array}{l}\text { Chloride } \\
\text { (mEq/L) }\end{array}$ & 91 & 96 & 87 & 108 & 95 & 94 & 97 & 89 \\
\hline $\begin{array}{l}\text { Phosphorous } \\
\text { (mg/dL) }\end{array}$ & 4.8 & ND & 6.3 & 2.6 & $<1.0$ & 3.1 & 4.5 & 3.9 \\
\hline BUN (mg/dL) & 26 & 17 & 33 & 3.8 & 13 & 22 & 6 & 80 \\
\hline $\begin{array}{l}\text { Creatinine } \\
(\mathrm{mg} / \mathrm{dL})\end{array}$ & 1.50 & 1.18 & 2.39 & 1.89 & 1.01 & 0.98 & 0.50 & 1.80 \\
\hline AST (U/L) & 15 & 14 & 294 & 72 & 30 & 29 & 22 & 227 \\
\hline ALT (U/L) & 21 & 15 & 151 & 58 & 35 & 25 & 58 & 120 \\
\hline ESR (mm/hr) & 131 & 76 & 29 & 32 & 90 & 73 & 83 & 42 \\
\hline CRP (mg/L) & 243.7 & 293.6 & 271.4 & 199.8 & 214 & 70.6 & 363.2 & 233.9 \\
\hline $\begin{array}{l}\text { Ferritin } \\
(\mathrm{ng} / \mathrm{mL})\end{array}$ & 371 & 651 & 3,546 & 659 & 1,339 & 1,434 & 1,452 & 3,511 \\
\hline LDH (U/L) & 340 & 327 & 1,479 & 510 & 289 & 281 & 527 & 726 \\
\hline $\begin{array}{l}\text { D-dimer } \\
\text { (mcg/mL) }\end{array}$ & ND & 1.37 & 20 & 19.14 & 0.74 & 2.24 & 0.94 & 9.34 \\
\hline $\begin{array}{l}\text { Fibrinogen } \\
\text { (mg/dl) }\end{array}$ & ND & 651 & 631 & 811 & ND & ND & 798 & ND \\
\hline $\begin{array}{l}\text { Insulin IV or } \\
\text { SC }\end{array}$ & IV & IV & IV & IV & IV & IV & IV & IV \\
\hline $\begin{array}{l}\text { Acute renal } \\
\text { replacement } \\
\text { therapy }\end{array}$ & None & None & Hemodialysis & None & None & None & None & None \\
\hline Intubated & No & No & Yes & Yes & No & No & No & Yes \\
\hline $\begin{array}{l}\text { Treatment of } \\
\text { CovID-19 }\end{array}$ & $\begin{array}{l}\text { HCQ, } \\
\text { doxycycline }\end{array}$ & $\begin{array}{l}\text { HCQ, } \\
\text { azithromycin }\end{array}$ & $\begin{array}{l}\text { Cefepime, } \\
\text { azithromycin, } \\
\text { vancomycin }\end{array}$ & $\begin{array}{l}\text { HCQ, ceftriaxone, } \\
\text { azithromycin }\end{array}$ & $\begin{array}{l}\text { HCQ, } \\
\text { azithromycin }\end{array}$ & $\begin{array}{l}\text { HCQ, } \\
\text { azithromycin }\end{array}$ & $\begin{array}{l}\mathrm{HCQ}, \\
\text { azithromycin }\end{array}$ & $\begin{array}{l}\mathrm{HCQ} \text {, } \\
\text { ceftriaxone, } \\
\text { azithromycin }\end{array}$ \\
\hline Outcom & Discharged & ischarged & Died & $\mathrm{Di}$ & Discharge & Discharged & Discharged & Died \\
\hline
\end{tabular}

\section{TABLE 1: Summary of pertinent clinical characteristics and laboratory values.}

Reference ranges are as follows: Hemoglobin A1c 4\%-6\%, pH 7.36-7.44, bicarbonate 21-31 mEq/L, glucose 70-110 mg/dL, anion gap 3-10 $\mathrm{mEq} / \mathrm{L}$, effective osmolarity $283-299 \mathrm{mOsm} / \mathrm{kg}$, white cell count $4.5-11 \mathrm{~K} / \mathrm{mm}^{3}$, hemoglobin $12-16 \mathrm{~g} / \mathrm{dL}$, platelets $140-440 \mathrm{~K} / \mathrm{mm}^{3}$, troponin less than $0.03 \mathrm{ng} / \mathrm{ml}$, sodium 135-145 mEq/L, potassium 3.5-5 mEq/L, chloride 98-107 mEq/L, phosphorus 2.5-5 mg/dL, BUN 7-23 mg/dL, creatinine 0.6-1.30 $\mathrm{mg} / \mathrm{dL}$, AST 13-39 U/L, ALT 7-52 U/L, ESR 0-10 mm/hr, CRP less than $10 \mathrm{mg} / \mathrm{L}$, ferritin 12-300 ng/ml, LDH 140-271 U/L, d-dimer less than 0.5 $(\mathrm{mcg} / \mathrm{mL})$, fibrinogen $183-503 \mathrm{mg} / \mathrm{dl}$.

M, Male; F, female; DM, diabetes; undiagnosed, first time diagnosed with diabetes; HTN, hypertension; DLD, dyslipidemia; BPH, benign prostatic hyperplasia; SOB, shortness of breath; NR, not reported; NA, not applicable; DPP4, dipeptidyl peptidase 4 inhibitor; SGLT2 inhibitor, sodium glucose co-transporter 2 inhibitor; BMI, body mass index; ND, not done; BUN, blood urea nitrogen; AST, aspartate transaminase; ALT, alanine transaminase; ESR, erythrocyte sedimentation rate; CRP, C-reactive protein; LDH, lactate dehydrogenase; IV, intravenous; SC, subcutaneous; HCQ, hydroxychloroquine.

The median age of the patient was 42.5 years (range 30-66 years), and seven were males and one was female. Ethnicity distribution in our patients: sex were Hispanic, one was African American, and one was Bengali. Comorbidities of the patients were hypertension, dyslipidemia, asthma, anxiety, and benign prostatic 
hyperplasia. Out of eight patients, five had type 2 DM, two were undiagnosed with DM, and one had type 1 DM. Presenting complaints included generalized weakness, fatigue, SOB, cough, fever, chills, dizziness, nausea, vomiting, abdominal pain, chest pain, and blood in stools. One patient was taking SGLT 2 inhibitors (known to increase the risk of ketoacidosis). Median value of initial glucose on presentation was $454 \mathrm{mg} / \mathrm{dL}$. Median value of HbA1c on presentation was $11.4 \%$ and of anion gap was $26.5 \mathrm{mEq} / \mathrm{L}$. Four patients had large ketonemia, one patient had moderate ketonemia, and three patients had small ketonemia. All the patients were started on standard treatment protocol for DKA with intravenous fluids and IV insulin infusion. Inflammatory markers (CRP, ferritin) were elevated in all the patients. Acute kidney injury (AKI) was seen in four patients, and one patient required renal replacement therapy. Out of eight patients, three required mechanical ventilation, and the same three patients died.

\section{Discussion}

It is estimated that in 2018 , in the United States, about $10.5 \%$ of the population had diabetes, while $21.4 \%$ of the patients that have diabetes are unaware. Diabetes is known to cause both microvascular and macrovascular complications, and patients with diabetes have multiple coexisting conditions and complications. In 2017, the total direct and indirect estimated cost of diagnosed DM in the United States was $\$ 327$ billion. In the last three decades, the number of patients with DM has quadrupled with specific races and ethnicities having disproportionate increases compared to others. With lifestyle changes, diabetes mellitus-related complications can be prevented [6].

Diabetic ketoacidosis is a potentially lethal complication of DM, often occurring more frequently in patients with DM type I. Observations during the COVID-19 pandemic have noted that patients with pre-existing diabetes may be at increased risk of DKA in the setting of COVID-19 infection [7]. Early data from Italy showed that $35.5 \%$ of patients that passed away with COVID-19 had coexisting diabetes [8]. Boddu et al. also evaluated the association between COVID-19-induced diabetes and pointed out a bidirectional link between COVID-19 and type 1 DM; though there is a hypothesis of new onset type I DM caused by COVID-19, no conclusive link has been made [9]. Further long-term studies that follow these patients will help us fully understand the connection between diabetes and COVID-19.

In the setting of the COVID-19 pandemic, unique considerations need to be applied to the management of DKA. The use of corticosteroids, specifically dexamethasone, has shown improved outcomes in patients hospitalized and requiring oxygen support [10]. With the use of corticosteroids for COVID-19 management, careful monitoring is required for hyperglycemia. Appropriate glycemic control and cessation of ketone production with insulin and correction of the fluid and electrolyte abnormalities are the cornerstone of DKA management; however, this requires extensive bedside patient interaction to monitor blood glucose, administer and titrate medications, and monitor rapid interventions for hypoglycemic events [11]. Though intravenous insulin has been the gold standard for management of DKA, there are unique considerations in the setting of COVID-19 pandemic as minimizing exposure to healthcare workers at bedside and preserving personal protective equipment become more important. In the setting of mild to moderate uncomplicated DKA, subcutaneous rapid-acting insulin every one to two hours is a safe and effective alternative [12].

Rubino et al. proposed that the virus, in binding to angiotensin-converting enzyme 2 (ACE2) receptors that are present in the beta cells of the pancreas, may cause pleiotropic alterations in glucose metabolism, which may ultimately exacerbate pre-existing diabetes or may even lead to a new mechanism of manifestation of disease [13]. Initial concerns originating from animal studies proposed that ACE2 expression may be upregulated in patients taking ACE inhibitors and angiotensin receptor blockers. These medications are frequently taken by diabetic patients for comorbidities. However, three subsequent studies, on various populations, did not provide evidence to support this hypothesis [14].

Most recent literature shows that diabetic patients with COVID-19 have an increased mortality. Early studies in April 2020 that consist of 5,700 patients hospitalized with COVID-19 in the New York city area showed that patients with diabetes were more likely to be have received invasive mechanical ventilation [1]. Guo et al. reported higher levels of inflammation-related biomarkers in DM patients compared to non-DM patients and DM as a risk factor for the progression and prognosis of COVID19 patients [15]. A retrospective cross-sectional study in COVID-19-infected patients showed that patients with diabetes were more likely to have longer length of stay (LOS) in hospital (14.4 days) as compared to the patients without diabetes (9.8 days) [16].

\section{Conclusions}

The case series we presented highlights there are great challenges in the co-management of COVID-19 and DKA. COVID-19 may precipitate DKA in patients with a history of DM or may even occur in patients with undiagnosed diabetes. In the setting of COVID-19 and DKA, patients who are mechanically ventilated do have a poorer outcome. Furthermore, DM patients have higher inflammation-related markers and longer LOS as compared to non-DM patients. Further studies are needed to address the pathophysiology and risk factors in order to understand better treatment strategies while addressing the unique circumstances of the COVID-19 pandemic. During the COVID-19 pandemic, in patients with DM, tight control of glucose levels and prevention of diabetes-related complications are of paramount importance to prevent severe courses of 
COVID-19. Healthcare providers should aim to reduce the exposure in vulnerable diabetes population.

\section{Additional Information \\ Disclosures}

Human subjects: Consent was obtained or waived by all participants in this study. St. Joseph Regional Medical Center (SJRMC) issued approval EX\#2020-29. IRB exempt from review. Animal subjects: All authors have confirmed that this study did not involve animal subjects or tissue. Conflicts of interest: In compliance with the ICMJE uniform disclosure form, all authors declare the following: Payment/services info: All authors have declared that no financial support was received from any organization for the submitted work. Financial relationships: All authors have declared that they have no financial relationships at present or within the previous three years with any organizations that might have an interest in the submitted work. Other relationships: All authors have declared that there are no other relationships or activities that could appear to have influenced the submitted work.

\section{References}

1. Richardson S, Hirsch JS, Narasimhan M, et al.: Presenting characteristics, comorbidities, and outcomes among 5700 patients hospitalized with COVID-19 in the New York city area. JAMA. 2020, 323:2052-2059. 10.1001/jama.2020.6775

2. Williamson EJ, Walker AJ, Bhaskaran K, et al.: Factors associated with COVID-19-related death using OpenSAFELY. Nature. 2020, 584:430-436. 10.1038/s41586-020-2521-4

3. Yang J, Zheng Y, Gou X, et al.: Prevalence of comorbidities and its effects in patients infected with SARSCoV-2: a systematic review and meta-analysis. Int J Infect Dis. 2020, 94:91-95. 10.1016/j.ijid.2020.03.017

4. Wang S, Ma P, Zhang S, et al.: Fasting blood glucose at admission is an independent predictor for 28-day mortality in patients with COVID-19 without previous diagnosis of diabetes: a multi-centre retrospective study. Diabetologia. 2020, 63:2102-2111. 10.1007/s00125-020-05209-1

5. Kim NY, Ha E, Moon JS, Lee YH, Choi EY: Acute hyperglycemic crises with coronavirus disease-19: case reports. Diabetes Metab J. 2020, 44:349-353. 10.4093/dmj.2020.0091

6. Zheng Y, Ley SH, Hu FB: Global aetiology and epidemiology of type 2 diabetes mellitus and its complications. Nat Rev Endocrinol. 2018, 14:88-98. 10.1038/nrendo.2017.151

7. Palermo NE, Sadhu AR, McDonnell ME: Diabetic ketoacidosis in COVID-19: unique concerns and considerations. J Clin Endocrinol Metab. 2020, 105:360. 10.1210/clinem/dgaa360

8. Onder G, Rezza G, Brusaferro S: Case-fatality rate and characteristics of patients dying in relation to COVID-19 in Italy. JAMA. 2020, 323:1775-1776. 10.1001/jama.2020.4683

9. Boddu SK, Aurangabadkar G, Kuchay MS: New onset diabetes, type 1 diabetes and COVID-19. Diabetes Metab Syndr. 2020, 14:2211-2217. 10.1016/j.dsx.2020.11.012

10. Horby P, Lim WS, Emberson JR, et al.: Dexamethasone in hospitalized patients with COVID-19 . N Engl J Med. 2021, 384:693-704. 10.1056/NEJMoa2021436

11. Korytkowski M, Antinori-Lent K, Drincic A, Hirsch IB, McDonnell ME, Rushakoff R, Muniyappa R: A pragmatic approach to inpatient diabetes management during the COVID-19 pandemic. J Clin Endocrinol Metab. 2020, 105:342. 10.1210/clinem/dgaa342

12. Palermo NE, Sadhu AR, McDonnell ME: Diabetic ketoacidosis in COVID-19: unique concerns and considerations. J Clin Endocrinol Metab. 2020, 105:dgaa360. 10.1210/clinem/dgaa360

13. Rubino F, Amiel SA, Zimmet P, et al.: New-onset diabetes in COVID-19. N Engl J Med. 2020, 383:789-790. 10.1056/NEJMc2018688

14. Jarcho JA, Ingelfinger JR, Hamel MB, D'Agostino RB Sr, Harrington DP: Inhibitors of the renin-angiotensinaldosterone system and COVID-19. N Engl J Med. 2020, 382:2462-2464. 10.1056/NEJMe2012924

15. Guo W, Li M, Dong Y, et al.: Diabetes is a risk factor for the progression and prognosis of COVID-19 . Diabetes Metab Res Rev. 2020, e3319. 10.1002/dmrr.3319

16. Alkundi A, Mahmoud I, Musa A, Naveed S, Alshawwaf M: Clinical characteristics and outcomes of COVID19 hospitalized patients with diabetes in the United Kingdom: a retrospective single centre study. Diabetes Res Clin Pract. 2020, 165:108263. 10.1016/j.diabres.2020.108263 